\title{
The Surgical Point of View of the Geriatric Patient - Urinary Incontinence
}

\author{
S. Madersbacher, J. Schmidbauer: G. Schatzl and H. C. Klingler
}

Keywords: Urinary incontinence - age - pathogenesis - diagnosis - treatment.

Schlüsselwörter: Harninkontinen- - Alter - Pathogenese - Diagnostik - Therapie.

Summary: Background: Urinary incontinence is one of the most frequent diseases in the ageing population. The aim of this manuscript is to present the current knowledge on urinary incontinence regarding (i) prevalence, (ii) pathogenesis, (iii) types. (iv) diagnostic assessment, and (v) treatment options.

Methods: The current literature regarding urinary incontinence with special reference to the geriatric patient was reviewed.

Results: According to a study performed recently in the Vienna area, $36.0 \%$ of women and $11.5 \%$ of men aged 70 years or older report urinary incontinence. Several factors, such as urodynamic changes. structural alterations of the lower urinary tract. increased sensory input. and impaired central control of the micturition reflex, contribute to the high prevalence of urinary incontinence with age. The four most common forms of urinary incontinence in the geriatric patient are combined stress/urge incontinence, pure urge incontinence, pure stress incontinence, and overflow incontinence. Diagnostic steps are classified into "mandatory". "recommended", and "indicated in selected cases only". Particularly the "mandatory tests" are simple to perform and need no special equipment. Therapeutic options should be directed to the type of urinary incontinence as well as the physical and mental status of the patient.

Conclusions: Urinary incontinence is highly prevalent with age. Conservative treatment is the therapy of choice for urge incontinence and mild to moderate forms of stress and overflow incontinence in the geriatric patient.

(Acta Chir. Austriaca 2001; 33:271-274)

\section{Der geriatrische Patient aus chirurgischer Sicht - Harninkontinenz}

Zusammenfassung: Grundlagen: Die Harninkontinenz zählt bei beiden Geschlechtern zu den häufigsten Alterserkrankungen. Das Ziel dieser Arbeit ist es, den gegenwärtigen Stand des Wissens hinsichtlich (i) Prävalenz, (ii) Pathogenese, (iii) Diagnostik und (iv) Therapie der Harninkontinenz unter besonderer Berücksichtigung des geriatrischen Patienten darzulegen.

Methodik: Die aktuelle Literatur über die verschiedenen Aspekte der Harninkontinenz des geriatrischen Patienten wird zusammengefaßt.

Ergebnisse: Wie im Rahmen einer kürzlich im Großraum Wien durchgeführten Studie gezeigt werden konnte, geben $36,0 \%$ der Frauen und 11,5\% der Männer älter als 70 Jahre eine Harninkontinenz an. Eine Reihe von Pathomechanismen wie urodynamische und strukturelle Veränderungen des unteren Harntraktes, verstärkte sensorische Afferenzen aus dem Blasenbereich sowie eine zentrale Beeinträchtigung der Kontrolle des Miktionsreflexes verursachen die Haminkontinenz im Alter. Die vier häu-

Corresponding address: S. Madersbacher, M.D., Department of Urology, University of Berne, Inselspital, Switzerland.

Fax: $++44 / 31 / 6322180$

E-mail: madersbacher@hotmail.com figsten Formen des Harninkontinenz beim alternden Menschen sind die gemischte Drang/Streßinkontinenz, die reine Dranginkontinenz. die reine Streßinkontinenz sowie die Überlaufinkontinenz. Die Untersuchungsschritte zur Abklärung inkontinenter. älterer Menschen werden in (i) erforderliche, (ii) emptohlene und (iii) im Einzelfall indizierte Untersuchungsschritte unterteilt. Vor allem die erforderlichen Untersuchungen sind einfach und von nahezu jedem Arzt durchzufühen. Die Therapie der Harninkontinenz im Alter richtet sich nach dem Pathomechanismus, der Inkontinenzform. dem Allgemeinzustand sowie sozialem Umfeld.

Schlußfolgerungen: Die Harninkontinenz zählt zu den häufigsten Erkrankungen des alternden Menschen. Die konservative Therapie ist die Therapie der Wahl bei Patienten mit Dranginkontinenz. und als Primärtherapic bei mild bis mäßig ausgeprägter Streßinkontinenz sowie der Überlaufinkontinenz.

\section{Introduction}

Voiding dysfunctions in the elderly belong to the most common gerontological problems, being more frequent than cardiovascular disorders or rheumatoid arthritis, and have far-reaching medical, psychological. and socio-economic implications $(5,6,13$, 18, 24, 26, 27, 29). Urinary incontinence as defined by the International Continence Society (ICS) is a "condition in which involuntary loss of urine is a social or hygienic problem and is objectively demonstrable". Along with micturition symptoms, urinary incontinence is highly prevalent with advanced ageing (see below) (29). Economic costs to the health care system for the diagnosis and therapy of urinary incontinence are substantial. In Germany. more than one billion US dollars are spent annually for incontinence devices. which is more than for hacmodialysis or coronary artery bypass surgery taken together (24). The continuously ageing population in industrialised countries further emphasises the socio-economic implications of this condition. In Austria. the number of individuals aged $>75$ years will increase from about 550,000 in $1998(6.8 \%$ of the total population) to almost a million by the year 2030 (12.1\% of the total population) (table 1). The aim of this manuscript is to review the current knowledge on (i) the prevalence of urinary incontinence, (ii) the pathogenesis of urinary incontinence, (iii) diagnostic assessment, and (iv) therapy of urinary incontinence, all with particular reference to the situation in elderly individuals.

\section{Prevalence of urinary incontinence}

When assessing prevalence rates of urinary incontinence, one is faced with a number of methodological problems as different definitions of urinary incontinence (subjective and/or objective data), target populations (ambulatory, institutionalised), sampling techniques and study designs (mailed or telephone surveys, personal interviews) are used (29). This inconsistency resulted in large differences in the reported prevalence rates. For women, the respective percentages range from $8 \%$ to $53 \%$ (29). A further problem is the fact that only few studies have assessed the impact of this frequent condition on quality of life ("bother factor"). We have recently completed a large-scale study of almost 2500 individuals who participated in a health survey in the area of Vienna. all of whom completed a detailed urinary incontinence questionnaire (29). In all, 1236 men ( $\mathrm{m}$; $48.6 \pm 13.0 \mathrm{yr}$; range: $20-96 \mathrm{yr}$ ) and 1262 women (f; $49.7 \pm 13.6 \mathrm{yr}$; range: 20 $96 \mathrm{yr}$ ) were analysed. Of these, $26.3 \%$ of women and $5 \%$ of men reported incontinence episodes during the previous 4 weeks (29). The prevalence of urinary incontinence increased con- 
Table 1. Demographic changes within the nevt decades in Austria.

\begin{tabular}{|l|l|l|c|l|}
\hline & \multicolumn{2}{|l|}{ Absolute } & \multicolumn{2}{l|}{ \% of the total population } \\
\hline & $\mathbf{7 5}+\mathbf{y r}$ & $\mathbf{8 5}+\mathbf{y r}$ & $\mathbf{7 5 + \mathbf { y r }}$ & $\mathbf{8 5 + \mathbf { y r }}$ \\
\hline 1970 & 350.229 & 53.004 & 4.7 & 0.7 \\
\hline 1990 & 534.858 & 104,391 & 6.9 & 1.4 \\
\hline 1998 & 548.879 & 143,927 & 6.8 & 1.8 \\
\hline 2015 & 729.619 & 209.074 & 9.1 & 2.6 \\
\hline 2030 & 977.206 & 295.841 & 12.1 & 3.7 \\
\hline
\end{tabular}

Modified from Kvir; Geriatrie Praxis Österreich hiyy

Table 2. Pathomechanisms leading to trinan incontinence.

\begin{tabular}{|l|l|}
\hline Urge incontinence & increased sensory input \\
\hline & impaired central control \\
\hline & alterations of the detrusor \\
\hline Stress incontinence & idiopathic \\
\hline & hypermobile bladder neck \\
\hline & hypotonic urethra \\
\hline Overflow incontinence & weakness of the external sphincter \\
\hline & detrusor failure \\
\hline & bladder outflow obstruction \\
\hline
\end{tabular}

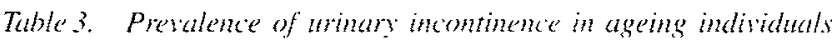
(excluding newrogenic and extrasphinderic incontinence).

\begin{tabular}{|l|l|l|}
\hline & Women & Men \\
\hline Combined stress/urge incontinence & $45 \%$ & $40 \%$ \\
\hline Pure urge incontinence & $30 \%$ & $30 \%-40 \%$ \\
\hline Pure stress incontinence & $15 \%-20 \%$ & $5 \%-10 \%$ \\
\hline Overflow incontinence & $5 \%$ & $5 \%-10 \%$ \\
\hline
\end{tabular}

stantly with age: $20-29$ yr: $4.1 \%$ (f). $1.7 \%(\mathrm{~m}) ; 30-39$ yr: $10.8 \%(\mathrm{f}) .2 .7 \%(\mathrm{~m}) ; 40-49$ yr: $22.9 \%(\mathrm{f}) .3 .9 \%(\mathrm{~m}) ; 50-59 \mathrm{yr}:$ $34.9 \%(\mathrm{f}), 3.7 \%(\mathrm{~m}) ; 60-69$ yr: $36.9 \%$ (f). $7.6 \%(\mathrm{~m}) ; 70+\mathrm{yr}:$ $36.0 \%(\mathrm{f}) .11 .5 \%(\mathrm{~m})$. The risk for urinary incontinence was 6.8 -fold higher for women $(5.1 \%-9.1 \% .95 \% \mathrm{CI} ; P<0.0001)$ (29). Overall, $65.7 \%$ of women and $58.3 \%$ of men reported a quality of life impairment by urinary incontinence. According to these data, about 560,000 women $(17.3 \%$ of the total female population $\geq 20 \mathrm{yr})$ and 105,000 men $(2.9 \%$ of the total population $\geq 20 \mathrm{yr}$ ) currently living in Austria "suffer" from urinary incontinence, i.e. indicate a quality of life impairment (29). In individuals aged 70 years or older, the respective percentages are in the range of $25 \%-30 \%$ for women and up to $10 \%$ for men (29).

\section{Pathogenesis}

\section{Age-related histological changes in the lower urinary tract}

With age, a number of structural changes in the lower urinary tract are demonstrable; the most intensively studied organ in this respect is the urinary bladder $(7,8)$. Mark et al. determined the detrusor contractility of 67 patients aged 24 to 82 years in vitro (23). The maximum flow rate decreased with advanced age, yet detrusor contractility assessed by an in vitro test remained constant (23). Gilpin et al. reported on a reduction in the number of nerves in the urinary bladder with progressing age (11). Levi et al. observed a significant increase of collagen fibres in the submucosa and around the neurovascular bundles, and Ewalt et al. noticed a replacement of elastin by collagen within the muscle fibres. accompanied by increased collagen deposits at the basal membrane (10, 17). These findings might explain the reduced elasticity and. potentially. the reduced bladder capacity of the ageing detrusor (20). The most comprehensive studies regarding this issue were reported by Elbadawi et al. (7-9). Four different ultrastructural patterns were identified in the human detrusor. each of which correlated with a distinct urodynamic finding (79). The "dense band pattern" correlated with a normal ageing bladder, the "dysjunction pattern" with detrusor instability, "myohypertrophy" with outflow obstruction, and "widespread degeneration" with an acontractile detrusor (7-9). The authors proposed that the dense pattern represents the structural norm of the ageing detrusor, heralds a process of muscle cell dedifferentiation in the detrusor accompanying natural ageing, and may affect exchange and storage of ions involved in the excitation-contraction coupling mechanism of muscle cells through depletion of caveolae (7-9).

\section{Age-related urodynamic changes}

The impact of age on results of uroflowmetry, residual volume, and urodynamic parameters such as bladder capacity, voided volume, or detrusor pressure is comparable for both sexes $(19,22)$. These data provide the urodynamic basis for the repeatedly published observation that ageing women report similar voiding disturbances as men $(4,16,21)$. These similarities are stunning, as higher age is associated with opposite developments intravesical in both sexes. In women. there is a highly significant reduction in the maximum urethral closing pressure and in the functional urethral length, indicating a decrease in outflow resistance (22). In contrast, there is an increase in prostate volume with age in men $(19,22)$. The reduction in maximum flow rates in both sexes is most likely due to a decrease in voided volume seen with advancing age. Detrusor instability is highly prevalent with age (19, 22). In elderly men with lower urinary tract symptoms, we could demonstrate a significant age-related increase in detrusor instability: such a phenomenon was not demonstrable in women with different types of urinary incontinence (22). Yet the overall incidence of detrusor instability was significantly higher in females than in males ( $48 \%$ vs. $33 \%$ ) (22). Ageing lower urinary tract function in both sexes is urodynamically characterised by a reduction in peak and average flow rates, voided volume, and bladder capacity and by a high incidence of detrusor instability (22). These data suggest a primary nongender-specific ageing process of the human urinary bladder (22).

\section{Types of urinary incontinence}

Urinary incontinence is classified into five different forms: (i) stress incontinence, (ii) urge incontinence, (iii) overflow incontinence, (iv) neurogenic incontinence, and (v) extrasphincteric incontinence (table 2). Neurogenic and extrasphincteric incontinence are only rarely seen in elderly individuals and are therefore not discussed here. Table 3 demonstrates the frequency of the three most common forms of urinary incontinence in elderly women and men. In women, the two most common forms are combined stress/urge and pure urge incontinence; overflow incontinence is present in only $5 \%$ of cases. A similar pattern is seen in men, yet overflow incontinence is demonstrable in up to $10 \%$ of cases.

\section{Stress urinary incontinence}

Stress urinary incontinence is defined by urinary leakage during physical exercise without feeling the urge to void. The pathognomonic clinical finding is urinary leakage synchronous with stress manoeuvres such as coughing or heavy lifting. Hence, stress urinary incontinence is caused by an incompetent urethral closure. This closure mechanism is mediated by the following three components (table 2):

Component I: Anatomical structures of the urethra (striated and smooth muscles, mucosa, submucosal vessels, connective tissue) mediate the urethral closing pressure. In continent individuals, passive urethral closing pressure is higher than the intravesical pressure, thus providing urinary continence during rest. 
Component II: Describes the passive pressure transmission requiring an intact pelvic floor.

Component III: Describes the active pressure transmission and requires an intact innervation via the nervus pudendus.

Stress urinary incontinence occurs if one of the above-mentioned components is deficient, either in isolation or in combination. A deficiency of one component can be compensated by another component.

\section{Urge urinary incontinence}

Patients with urge incontinence report urinary leakage associated with a strong urge to void without physical exercise, typically before they can reach a toilet. Urge incontinence is either caused by detrusor hyperactivity or hypersensitivity and is the consequence of a misbalance between sensory input and lack of central inhibition of the micturition reflex. Lrae urinary incontinence is caused by four pathomechanisms that. like stress urinary incontinence. occur either in isolation or in combination (table 2).

(i) Decreased inhibition of the micturition reflex: Various neurological diseases, such as encephalitis disseminata, Parkinson's disease. or cerebral insults, can lead to detrusor hyperactivity via incomplete lesion of the spine or deficient central control If the lesion is below the micturition centre (which is located in the brain stem), detrusor hyperreflexia is combined with detrusor sphincter dyssynergia; if the lesion is above the micturition centre, voiding is usually co-ordinated.

(ii) Increased sensory input: If sensory input is increased substantially (e. g. by acute/chronic urinary tract infection, bladder tumours, bladder stones, or atrophic vaginitis caused by oestrogen deficiency). even an intact cortex decompensates, resulting in detrusor hyperactivity. Detrusor hyperactivity is seen in about $50 \%$ of elderly men with lower urinary tract symptoms (LUTS) due to benign prostatic enlargement (BPE).

(iii) Structural alterations in the detrusor: As indicated above (see age-related structural changes in the lower urinary tract), a number of structural changes occur with ageing. Ultrastructural analyses have shown that the ageing detrusor is characterised by altered cell-to-cell contacts (protrusion junctions), which shorten the distance between smooth muscle cells, thus facilitating muscle cell stimulation.

\section{(iv) Idiopathic urge incontinence}

\section{Overflow incontinence}

In individuals with high post-void residual volumes (usually $>300-500 \mathrm{ml}$ ), overflow incontinence is present when additional bladder filling leads to urinary incontinence. This form of urinary incontinence can only be diagnosed by measurement of the post-void residual volume. The two major pathomechanisms leading to overflow incontinence are primary detrusor failure and significant bladder outflow obstruction (usually benign prostatic enlargement in men; severe bladder outflow obstruction is rare in women) (table 2). If overflow incontinence is present for a prolonged period of time, detrusor failure is inevitable, which generally can only be managed by intermittent or permanent catheterisation of the urinary bladder.

\section{Diagnostic assessment}

According to the Guidelines of the International Continence Society and the Urodynamic Working Group of the Austrian Society of Urology. potential investigations on incontinent individuals have to be classified into obligatory, recommended, and indicated in selected cases only. There is no major difference regarding the diagnostic work-up of younger or older individuals with urinary incontinence, yet the indication for more invasive procedures (e.g. urodynamics) should be carefully balanced against the potential diagnostic gain and therapeutic consequence.

The following investigations should be obtained for every patient in whom urinary incontinence is suspected (obligatory investigations):
- medical history specifically addressing the following issues: duration and frequency of urinary incontinence. circumstances under which urinary incontinence occurs, usage of incontinence devices, voiding symptoms, nocturia. etc.

- physical examination

- neurourological examination (sensibility in S2-S5: sacral retTexes)

- a stress test to demonstrate the presence of urinary incontinence

- urinalysis to exclude the presence of urinary tract infection

- determination of post-void residual volume

\section{Recommended investigations}

These investigations are particularly recommended in the event of primary therapy failure or prior to surgical therapy: standardised PAD test to quantify urine loss (e. g. during 15 minutes of physical exercise), assessment of renal function, uroflowmetry, urodynamic study, radiological studies (urethrocystogram, voiding cystourethrogram. intravenous pyelogram). and endoscopy of the lower urinary tract.

\section{Investigations indicated in selected cases}

These include additional urodynamic tests (resting and stress urethral pressure profile. flow EMG, video-urodynamics). Valsalva or cough leak point pressure, neurophysiological tests, and more elaborate imaging modalities (dynamic MRI of the pelvic floor and the spine, SPECT, and PET scan).

\section{Treatment}

\section{Stress incontinence}

In cases with mild and moderate degrees of stress, urinary incontinence physiotherapy, which aims al strengthening the pelvic floor and the sphincter apparatus, is the therapy of choice $(2,3)$. Ideally, physiotherapy should be initiated as a group therapy to enhance motivation and self-confidence. The inclusion of biofeedback techniques and group therapy can be helpful (14).

Adjunct conservative measures include weight reduction in overweight individuals, fluid restriction, instruction to void at regular time intervals, and bowel regulation. For elderly individuals with cystourethroceles or high-grade descensus who refuse to undergo surgery. a vaginal ring pessary should be considered.

The benefit of medical therapy for stress urinary incontinence is controversially discussed. The role of local or systemic oestrogen therapy in postmenopausal women with pure stress incontinence is uncertain: however, accompanying urgency or urge incontinence can be ameliorated. The positive effect of alphaadrenergic drugs has not been convincingly documented in placebo-controlled randomised clinical trials to date.

In younger individuals, too, surgery should be considered for all cases with severe forms of stress urinary incontinence or where conservative measures have failed (1). It is beyond the scope of this manuscript to describe the different surgical approaches (1). The two major options are colposuspension (Burch operation) or vaginal bladder-neck suspension (1). Due to a more favourable long-term outcome, colposuspension is currently considered the therapy of choice. Within the past years, several minimally invasive procedures, such as TVT (tension free vaginal tape) or newer forms of bulking agents (e.g. implantable microballoons), have been developed. The long-term outcome of these approaches is currently under investigation (25).

\section{Urge incontinence}

At all ages, treatment of urge urinary incontinence is primarily conservative. Pathomechanisms leading to an increased sensory input, such as chronic urinary tract infection, bladder tumours or stones, bladder outflow obstruction, or oestrogen deficiency in women, should be corrected first. These measures usually improve symptomatology in a substantial number of patients. To compensate for a central deficiency (impaired inhibition of the micturition reflex), "toilet training" (voluntary voiding before a strong urge to void leats to urge incontinence) and "micturition training" (active, step-wise increase of micturition intervals) are 
helpful. Undoubtedly, the cornerstone therapy for urge urinary incontinence are anticholinergic drugs that relax the hyperactive detrusor (28,30). In Austria, three different drugs are currently available: Oxybutinine. Tolterodine, and Trospiumchloride, all of which have a comparable clinical efficacy. The major anticholinergic side-effects, particularly in the elderly, are dry mouth and constipation. One advantage of Tolterodine is that it binds to anticholinergic receptors in the salivary gland 8 times less strongly than Oxybutinine (12). Particularly in elderly individuals with sicca syndrome. Tolterodine and Trospiumchloride are advantageous. If anticholinergic drugs are not effective or not tolerated. neuromodulation or neurostimulation (ambulatory or at home) is another conservative, valid treatment option.

\section{Over-flow incontinence}

Appropriate treatment of overflow incontinence requires a thorough diagnostic work-up including urodynamics; the respective patients should therefore be referred to a specialist. If bladder outflow obstruction is excluded and a primary detrusor failure is present, intermittent or permanent (transurethral/suprapubic) catheterisation is the therapy of choice. Specially designed transurethral bridge catheters, which have recently been developed, are attractive alternatives (15). Their long-term efficacy, however, is currently unknown and the treatment failure rate in badly selected cases is substantial (15). If bladder outflow obstruction usually due to benign prostatic enlargement can be documented by urodynamics (preferable: pressure-flow study), prostatectomy is usually indicated.

It needs to be emphasised that a number of drugs (e. g. anticholinergics, spasmolytics, antidepressives. psychopharmaceuticals, Ca-antagonists) can lead to detrusor insufficiency: therefore careful assessment of concurrent medication is mandatory.

\section{References}

(1) Butler RN, Maby JI, Montella JM, Young GP: Lrinary incontinence: when 10 refer for procedural therapies. Geriatrics 1999;54: 49-54.

(2) Burgio KL: Behaviour training for stress and urge incontinence in the commun ity. Gerontology 1990;36(Suppl.2): 27-34

(3) Burgio KL, Locher J, Goode P: Behavioural versus drug treatment for urge in continence in older women. JAMA 1998:280: 1995-2000.

(4) Chancellor MB, Rivas DA: American urological association symptom index for women with voiding symptoms: lack of index speciticity for benign prostatic hyperplasia. J Urol 1993:150: 1706-1709.

(5) Diokno AC, Brock BM, Brown MB. Herzog AR: Prevalence of urinary incontinence and other urological symptoms in the noninstitutionalized elderly. I Uro 1986:136: 1022-1025.

(6) Diokno AC, Brown MB, Goldstein N, Herzog AR: Epidemiology of biadder emptying symptoms in elderly men. J Urol 1992:148: 1817-1821.

(7) Elbadawi A, Diokno AC, Millard RJ: The aging bladder: morphology and uro dynamics. World J Urol 1998;16(Suppl.1): S10-34.
(8) Elbadawi A. Yalla SV. Resnick NM: Structural basis of geriatric voiding dysfunction. I. Methods of a prospective ultrastructural/urodynamic study and an overview of the findings. J Lrol 1993:150: 1650-1656.

(9) Elbadawi A, Yalla SV. Resnick NM: Structural basis of geriatric voiding dysfunction. II. aging detrusor: normal versus impaired contractility. J Urol 1993:150) $1657-1667$.

(10) Ewalt DH. Howard PS, Blyth B. Snyder HM HIl. Duckett JW, Levin RM Macarak EJ: Is lamina propria matrix responsible for normal bladder compliance? J Urol 1992:148: $5+4-549$

(11) Gilpin SA. Gitpin CJ. Dixon IS. Gosling JA. Kirby RS: The effect of age on the autonomic innervation of the urinary bladder. $\mathrm{Br} J$ Urol $1986.58: 378-381$.

(12) Guay DR: Tolterodine. a new antimuscarinic drug for treatment of bladder overactivity. Pharmacotherapy 1999:19:276-280.

(13) Johnson TM II. Ouslander JG: Urinary incontinence in the older man. Med Clin North Am 1999:83: 1247-1266.

(14) Kartoso LD. Stanton LS: Biofeedback: a five-year review. Br J Urol 1984:56 $22-26$

(15) Klingler HC Kiss G. HaB M. Madersbacher H: Der In-Flow Katheter: Indikation und Ergebnisse. Der Lrologe [A] 1999:38(Suppl. I): S51.

(16) Lepor $H$. Machi G: Comparison of AUA symptom index in unselected males and females between fifty-five and seventy-nine years of age. Urology 1993;42 $36-41$.

(17) Levi BJ, Wight TN: Structural changes in the aging submucosa: new morphologic criteria for the evaluation of the unstable human bladder. J Urol 1990;144 $1044-1055$.

(18) Madersbacher S. Haidinger G. Tremml C. Schmidbauer CP for the Prostate Study Group of the Austrian Society of Urology: The prevalence of lower urinary tract symptoms in Austria as assessed by an open survey of 2096 men. Eur Urol 1998;34: 136-14I

(19) Madersbacher S. Klingler HC, Schatzl G. Stulnig T, Schmidbauer CP. Marberger $M$ : Age related urodynamic changes in patients with benign prostatic hy perplasia. J Urol 1996:156: 1662-1667

(20) Madersbacher S. Pycha A, Klingler CH, Mian C, Djavan B, Stulnig T, Mar berger M: Interrelationships of bladder compliance with age, detrusor instability. and obstruction in elderly men with lower urinary tract symptoms. Neurourol Urodyn 1999:18: 3-13

(21) Madersbacher S. Pycha A. Klingler CH. Schatzl G. Marberger M: The International Prostate Symptom Score in both sexes: a urodynamics based comparison Neurourol Urodyn 1999:18: 173-182.

(22) Madersbacher S. Pycha A, Schatzl G, Mian C. Klingler CH. Marberger M The asing lower urinary tract: a comparative urodynamic study of men and women. Urology $1998 ; 51: 206-212$

(23) Mark SD, Gilling PJ, van Mastrigt R. Arnold EP, McRae CU: Detrusor contractility: age related correlation with urinary flow rate in asymptomatic males Neurourol Urodyn 1992;11: 315-317.

(24) Melchior H: Voiding dysfunction in elderly patients. Urologe [A] 1995:34: 329-333.

(25) Pycha A, Klingler CH, Haitel A, Heinz-Peer G. Marberger M: Implantable microballoons: an attractive alternative in the management of intrinsic sphincter deficiency. Eur Urol 1998:33: 469-475.

(26) Resnick NM. Yalla SV: Detrusor hyperactivity with impaired contractile function. An unrecognized but common cause of incontinence in elderly patients. JAMA 1987:257: 3076-3081.

(27) Sirls LT, Rashid T: Geriatric urinary incontinence. Geriatr Nephrol Urol 1999:9: 87-89.

(28) Sullivan J. Abrams P: Pharmacological management of incontinence. Eur Urol 1999;36(Suppl.I): 89-95.

(29) Temml C. Haidinger G. Schmidbauer J, Schatzl G, Madersbacher S: Urinary Incontinence in both Sexes - Prevalence Rates. Impact on Quality of Life and Sexual Life. Neurourol Urodyn 2000:19: 259-27i.

(30) Wein AJ: Pharmacologic options for the overactive bladder. Urology 1998 51(2ASuppl): $43-47$. 